\title{
EFFECT OF METAL IONS ON THE ANAEROBIC SYNTHESIS OF SUPEROXIDE DISMUTASE IN ESCHERICHIA COLI
}

\author{
KOHICHIRO MIYAKE* AND SEIICHI HINO ${ }^{1}$ \\ Botanical Institute, Faculty of Science, Hiroshima University, \\ Naka-ku, Hiroshima 730, Japan \\ ${ }^{1}$ Hiroshima Jogakuin College, Ushida-Higashi 4-chome, Higashi-ku, \\ Hiroshima 730, Japan
}

(Received May 29, 1990)

\begin{abstract}
The effect of various metal ions on the anaerobic synthesis of superoxide dismutase (SOD) in Escherichia coli was examined. When cells were grown anaerobically by fermentation, adding $\mathrm{CuSO}_{4}$ in the culture medium resulted in the synthesis of manganese-containing SOD (Mn SOD), but adding $\mathrm{CrCl}_{3}, \mathrm{CoCl}_{2}, \mathrm{NiSO}_{4}, \mathrm{ZnSO}_{4}$ or $\mathrm{Ga}\left(\mathrm{NO}_{3}\right)_{3}$ did not. The presence of nitrate in culture medium stimulated the anaerobic synthesis of Mn SOD by $\mathrm{CuSO}_{4}$. During the incubation of resting cells under anaerobic conditions, the addition of $\mathrm{CuSO}_{4}$ and $\mathrm{KNO}_{3}$ increased $\mathrm{Mn}$ SOD activity, which was inhibited by chloramphenicol. Adding $\mathrm{CrCl}_{3}$ or $\mathrm{Ga}\left(\mathrm{NO}_{3}\right)_{3}$ with $\mathrm{KNO}_{3}$ increased $\mathrm{MnSOD}$ activity during anaerobic incubation of resting cells, but adding $\mathrm{MnCl}_{2},\left(\mathrm{NH}_{4}\right)_{2} \mathrm{Fe}\left(\mathrm{SO}_{4}\right)_{2}, \mathrm{~K}_{3} \mathrm{Fe}(\mathrm{CN})_{6}, \mathrm{CoCl}_{2}$, $\mathrm{NiSO}_{4}$ or $\mathrm{ZnSO}_{4}$ with $\mathrm{KNO}_{3}$ did not increase Mn SOD activity. Instead, they decreased it. The increase of Mn SOD activity in resting cells by $\mathrm{Cr}$ ions or $\mathrm{Ga}$ ions with nitrate was inhibited by ferric citrate but that by $\mathrm{Cu}$ ions was not. When cells were grown anaerobically with $\mathrm{CuSO}_{4}$ or when resting cells were incubated anaerobically with $\mathrm{CuSO}_{4}$, a new activity band of SOD appeared in the polyacrylamide gel electrophoreogram, regardless of the operation of nitrate respiration. The SOD of the new activity band was insensitive to cyanide, $\mathrm{H}_{2} \mathrm{O}_{2}$ or diethyldithiocarbamate. This new SOD and Mn SOD had the same molecular size but had different charges.
\end{abstract}

Escherichia coli has three types of superoxide dismutase (SOD): iron-containing SOD (Fe SOD) (20), manganese-containing SOD (Mn SOD) (7), and a SOD which consists of one of each of the subunits from the other two isozymes and contains both iron and manganese (Hybrid SOD) $(2,3)$.

* Address reprint requests to: Dr. Kohichiro Miyake, Botanical Institute, Faculty of Science, Hiroshima University, Naka-ku, Hiroshima 730, Japan. 
When $E$. coli cells are grown by oxygen respiration, cells contain the three types of SOD, but when $E$. coli cells are grown by fermentation, the cells contain only Fe SOD. In a previous study we showed that when $E$. coli cells were grown by nitrate respiration, the cells contained higher levels of Fe SOD than when grown by fermentation, and synthesized $\mathrm{Mn} \operatorname{SOD}$ and $\operatorname{Hybrid} \operatorname{SOD}(9,10)$. We also showed that nitrate respiration supplied both the ATP and proton motive force required for anaerobic induction of Fe SOD(11). Lodge and Emery $(8)$ reported that ferrienterobactin transport in $E$. coli cells, during anaerobic growth with nitrate, was inhibited by $\mathrm{KCN}$ or by dinitrophenol. This suggests that the operation of nitrate respiration stimulates the uptake of iron and that the increased intracellular $\mathrm{Fe}$ ions result in the anaerobic synthesis of Fe SOD. There are several reports that adding $\mathrm{Fe}$ ions or $\mathrm{Mn}$ ions to culture media or omitting $\mathrm{Fe}$ ions by chelating agents altered the SOD activity in $E$. coli $(4,12,14,16-19)$. In this study we examined the effect of metal ions other than Fe or Mn on SOD synthesis in E. coli. Under aerobic conditions, metal ions tend to generate oxygen-free radicals which are known to affect SOD synthesis. Therefore, even if SOD synthesis is affected by metal ions under aerobic conditions, it is difficult to determine whether the effect is due to metal ions per se or to oxygen-free radicals. Therefore, in this study we tested the effects of various metal ions on the synthesis of SOD in E. coli cells under anaerobic conditions.

\section{MATERIALS AND METHODS}

Bacteria and growth conditions. Escherichia coli K12 W1895 (Hfr, met) was used in this study.

The composition of the peptone-glucose medium (PSG medium) was Polypeptone (Wako) $10 \mathrm{~g},\left(\mathrm{NH}_{4}\right)_{2} \mathrm{SO}_{4} 1 \mathrm{~g}, \mathrm{MgSO}_{4} \cdot 7 \mathrm{H}_{2} \mathrm{O} 1 \mathrm{~g}, \mathrm{FeCl}_{3} \cdot 6 \mathrm{H}_{2} \mathrm{O} 2 \mathrm{mg}$, $\mathrm{MnSO}_{4} \cdot 4-6 \mathrm{H}_{2} \mathrm{O} 2 \mathrm{mg}$, glucose $2 \mathrm{~g}$ in $1,000 \mathrm{ml}$ of water; $\mathrm{pH}$ adjusted to 7.0. The culture method and the cell density measurement were as described previously (9).

Short term anaerobic incubation of resting cells. Cells were harvested by centrifugation, washed once with $0.1 \mathrm{M}$ citrate- $\mathrm{KOH}(\mathrm{pH} 7.2)$ and suspended in an incubation mixture containing $0.1 \mathrm{M}$ MOPS buffer ( $\mathrm{pH} 7.2$ ), $10 \mathrm{~mm}$ glucose, $25 \mathrm{~mm}$ $\left(\mathrm{NH}_{4}\right)_{2} \mathrm{SO}_{4}, 0.1 \%$ casamino acids and other additions such as nitrate or metal ions. The cell suspension $(120 \mathrm{ml})$ was put in a $250-\mathrm{ml}$ Sakaguchi-flask, then the gas phase of the flask was changed to pure $\mathrm{N}_{2}\left(\mathrm{O}_{2}\right.$ less than $\left.0.01 \%\right)$. The cell suspension was incubated for $4 \mathrm{~h}$ at $30^{\circ} \mathrm{C}$ on a reciprocating shaker at 120 strokes per min with an amplitude of $5 \mathrm{~cm}$. The cell density of the suspension was about $0.4 \mathrm{mg}$ of cell-protein per ml. In this incubation system, the increase or decrease of cell density as measured by the absorbance at $660 \mathrm{~nm}$ after incubation for $4 \mathrm{~h}$ was less than $20 \%$.

Assays. Cell-free extracts were prepared by sonic disruption of cells as described previously (9).

Protein was measured by the biuret reaction according to the method of Itzhaki and Gill (6). 
SOD isozymes were separated by electrophoresis on $7.5 \%$ polyacrylamide gels and visualized with activity stain according to the method of Beauchamp and Fridovich (1). The nondenatured molecular weights of SODs were estimated by the polyacrylamide gel method of Hedrick and Smith(5). Each gel was loaded with $100 \mu \mathrm{g}$ of protein and subjected to electrophoresis with $3 \mathrm{~mA}$ per gel at $4^{\circ} \mathrm{C}$.

\section{RESULTS}

Effect of metal ions on SOD synthesis in anaerobically growing cells

Several reports have shown that $\mathrm{Fe}$ ions or Mn ions affect SOD synthesis in $E$. coli, but there are few studies on the effect of other metal ions. Pugh et al. (16) examined the effect of various metal ions including $\mathrm{Fe}^{2+}, \mathrm{Mn}^{2+}, \mathrm{Cu}^{2+}, \mathrm{Co}^{2+}$, $\mathrm{Zn}^{2+}$ and $\mathrm{Ni}^{2+}$ on SOD synthesis, and found that only $\mathrm{Fe}^{2+}$ and $\mathrm{Mn}^{2+}$ significantly induced SOD, which was oxygen dependent. Schiavone and Hassan (18) reported that copper-cyanide complex induced anaerobic Mn SOD synthesis in E. coli but $\mathrm{CuSO}_{4}$ had no effect. We tested the effects of various metal ions, such as $\mathrm{Cr}^{3+}$, $\mathrm{Co}^{2+}, \mathrm{Ni}^{2+}, \mathrm{Cu}^{2+}, \mathrm{Zn}^{2+}$ and $\mathrm{Ga}^{3+}$, on $\mathrm{SOD}$ synthesis during anaerobic growth of $E$. coli cells. The results of Fig. 1 show that when cells were grown by nitrate respiration, $\mathrm{CuSO}_{4}$ increased $\mathrm{Mn}$ SOD activity (lane $\mathrm{G}$ ) but the other metal ions had little effect. When the cells were grown by fermentation, $\mathrm{CuSO}_{4}$ induced weak Mn SOD activity (lane B). In addition, when cells were grown anaerobically with $\mathrm{CuSO}_{4}$ by fermentation or nitrate respiration a weak new band of SOD activity appeared in the middle between Mn SOD and Hybrid SOD (lane B, G).

Effect of $\mathrm{Cu}$ ion on anaerobic SOD synthesis in resting cells

In the next experiment, we studied the effect of $\mathrm{CuSO}_{4}$ on SOD synthesis during anaerobic incubation of resting cells of $E$. coli. The results (Fig. 2) show that when $\mathrm{CuSO}_{4}$ and $\mathrm{KNO}_{3}$ were added to the suspensions of cells, which had grown by nitrate respiration, Mn SOD activity increased and the new SOD band

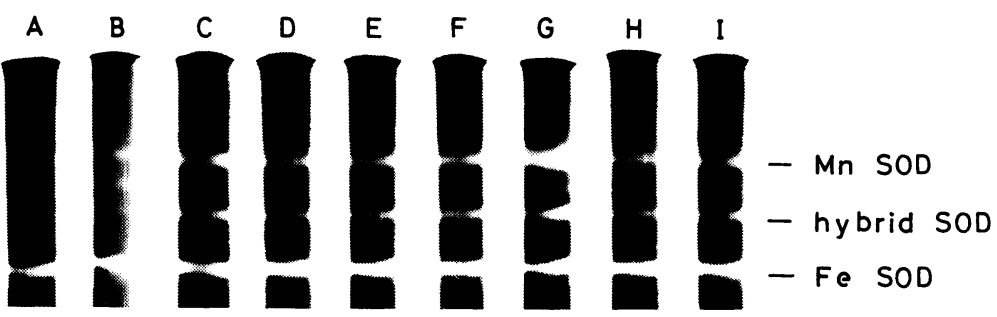

Fig. 1. Effect of metal ions on SOD synthesis in anaerobically growing cells of E. coli. Cells were cultured anaerobically for $18 \mathrm{~h}$ in PSG medium with the following additions. Lane A, no addition; Lane B, $100 \mu \mathrm{M} \mathrm{CuSO}_{4}$; Lane C, $40 \mathrm{~mm} \mathrm{KNO}$; Lane D, $100 \mu \mathrm{M}$ $\mathrm{CrCl}_{3}+40 \mathrm{mM} \mathrm{KNO}_{3}$; Lane E, $100 \mu \mathrm{M} \mathrm{CoCl}_{2}+40 \mathrm{mM} \mathrm{KNO}_{3} ;$ Lane F, $100 \mu \mathrm{M}$ $\mathrm{NiSO}_{4}+40 \mathrm{~mm} \mathrm{KNO}{ }_{3}$; Lane G, $100 \mu \mathrm{M} \mathrm{CuSO}_{4}+40 \mathrm{~mm} \mathrm{KNO}{ }_{3} ;$ Lane $\mathrm{H}, 100 \mu \mathrm{M}$ $\mathrm{ZnSO}_{4}+40 \mathrm{~mm} \mathrm{KNO}{ }_{3}$; Lane I, $100 \mu \mathrm{M} \mathrm{Ga}\left(\mathrm{NO}_{3}\right)_{3}+40 \mathrm{~mm} \mathrm{KNO}$. 


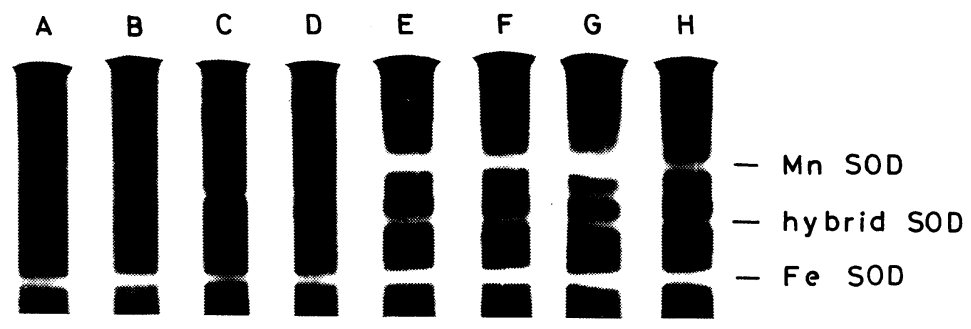

Fig. 2. Effect of $\mathrm{Cu}$ ion on anaerobic synthesis in resting cells of E. coli.

Lanes A to D, cells, cultured anaerobically without $\mathrm{KNO}_{3}$ for $18 \mathrm{~h}$, were harvested, washed and suspended in the incubation mixture, then incubated anaerobically for $4 \mathrm{~h}$ with the following additions. Lanes $\mathrm{E}$ to $\mathrm{H}$, cells, cultured anaerobically with $40 \mathrm{~mm} \mathrm{KNO}_{3}$ for $18 \mathrm{~h}$, were harvested, washed and suspended in the incubation mixture, then incubated anaerobically for $4 \mathrm{~h}$ with $40 \mathrm{~mm} \mathrm{KNO}_{3}$ and the following addition. Lane A and $\mathrm{E}$, no addition; lane B and $\mathrm{F}, 150 \mu \mathrm{g} / \mathrm{ml}$ chloramphenicol; lane $\mathrm{C}$ and $\mathrm{G}, 100 \mu \mathrm{M} \mathrm{CuSO}_{4}$; lane $\mathrm{D}$ and $\mathrm{H}, 100 \mu \mathrm{M} \mathrm{CuSO}_{4}+150 \mu \mathrm{g} / \mathrm{ml}$ chloramphenicol.

The composition of the incubation mixture was $0.1 \mathrm{M}$ MOPS buffer (pH 7.2), $10 \mathrm{~mm}$ glucose, $25 \mathrm{mM}\left(\mathrm{NH}_{4}\right)_{2} \mathrm{SO}_{4}$ and $0.1 \%$ casamino acids.

appeared in the middle between Mn SOD and Hybrid SOD bands (lane G). But when $\mathrm{CuSO}_{4}$ alone was added to cells, which had grown by fermentation, Mn SOD did not appear; only the new SOD appeared (lane C). The increase of Mn SOD and the appearance of the new SOD were inhibited by chloramphenicol (lane $\mathrm{D}, \mathrm{H}$ ). In the experiment with resting cells, adding $\mathrm{CuSO}_{4}$ stimulated anaerobic synthesis of Mn SOD only when $\mathrm{KNO}_{3}$ was simultaneously added, which is different from that with growing cells. The relationship between the stimulation of Mn SOD synthesis by $\mathrm{CuSO}_{4}$ and the operation of nitrate respiration was studied. The stimulation of $\mathrm{Mn}$ SOD synthesis in resting cells by adding $\mathrm{CuSO}_{4}$ required both glucose and nitrate (data not shown). However when nitrate was replaced with nitrite, $\mathrm{CuSO}_{4}$ did not stimulate the Mn SOD synthesis in resting cells (data not shown). These results show that the stimulation of Mn SOD synthesis in resting cells by $\mathrm{CuSO}_{4}$ requires the operation of nitrate respiration.

\section{Effect of metal ions on anaerobic SOD synthesis in resting cells}

In the experiment on the SOD activity of growing cells (Fig. 1), the PSG medium contained $\mathrm{FeCl}_{3}$. Since $\mathrm{Fe}$ ion is known to repress $\mathrm{Mn}$ SOD synthesis in E. $\operatorname{coli}(12,16,17,19)$, it was necessary to test the effect of metal ions on SOD in the absence of $\mathrm{Fe}$ ions. Therefore, the effects of $\mathrm{Cr}^{3+}, \mathrm{Mn}^{2+}, \mathrm{Fe}^{2+}, \mathrm{Fe}^{3+}, \mathrm{Co}^{2+}$, $\mathrm{Ni}^{2+}, \mathrm{Zn}^{2+}$ and $\mathrm{Ga}^{3+}$ were tested on Mn SOD synthesis during incubation of resting cells in mixtures which did not contain Fe ions. The results (Fig. 3) show that adding $\mathrm{Cr}^{3+}$ or $\mathrm{Ga}^{3+}$ increased $\mathrm{Mn}$ SOD activity (lane $\mathrm{B}, \mathrm{I}$ ) but other metal ions did not increase the activity. Instead, they decreased it. The presence of $\mathrm{KNO}_{3}$ in the incubation mixture was necessary to stimulate SOD synthesis by $\mathrm{Cr}^{3+}$ or $\mathrm{Ga}^{3+}$ (data not shown). The new SOD, which was induced by adding $\mathrm{CuSO}_{4}$, was 


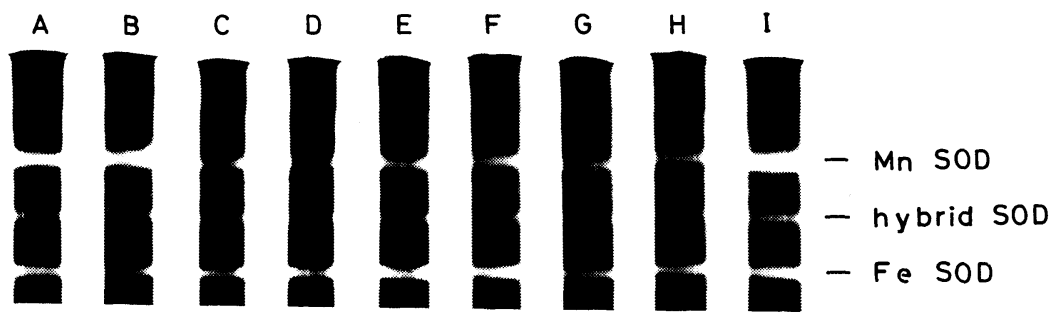

Fig. 3. Effect of metal ions on anaerobic SOD synthesis in resting $E$. coli cells.

Cells, cultured anaerobically with $40 \mathrm{mM} \mathrm{KNO}_{3}$ for $18 \mathrm{~h}$, were harvested, washed and suspended in the incubation mixture as described in Fig. 2, then incubated anaerobically for $4 \mathrm{~h}$ with $40 \mathrm{mM} \mathrm{KNO}_{3}$ and the following additions. Lane A, no addition; lane B, $100 \mu \mathrm{M}$ $\mathrm{CrCl}_{3}$; lane C, $100 \mu \mathrm{M} \mathrm{MnCl}_{2}$; lane D, $100 \mu \mathrm{M}\left(\mathrm{NH}_{4}\right)_{2} \mathrm{Fe}\left(\mathrm{SO}_{4}\right)_{2}$; lane E, $100 \mu \mathrm{M} \mathrm{K}_{3} \mathrm{Fe}(\mathrm{CN})_{6}$; lane F, $100 \mu \mathrm{M} \mathrm{CoCl}$; lane $\mathrm{G}, 100 \mu \mathrm{M} \mathrm{NiSO}_{4}$; lane $\mathrm{H}, 100 \mu \mathrm{M} \mathrm{ZnSO}_{4}$; lane I, $100 \mu \mathrm{M}$ $\mathrm{Ga}\left(\mathrm{NO}_{3}\right)_{3}$.

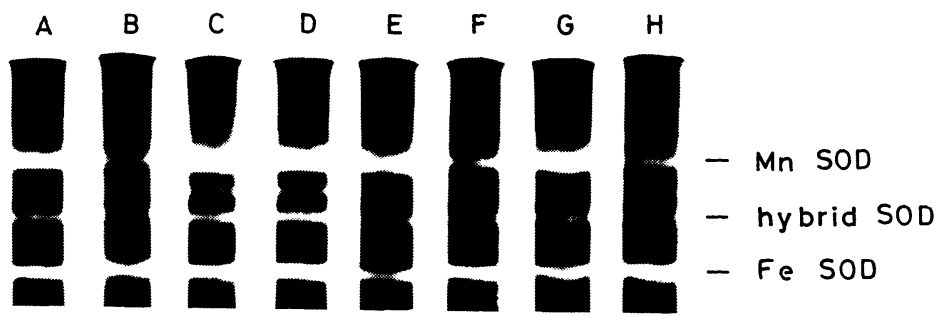

Fig. 4. Effect of ferric citrate on anaerobic SOD synthesis in resting cells of E. coli.

Cells, cultured anaerobically with $40 \mathrm{mM} \mathrm{KNO}_{3}$ for $18 \mathrm{~h}$, were harvested, washed and suspended in the incubation mixture containing $0.1 \mathrm{M}$ MOPS buffer $(\mathrm{pH} \mathrm{7.2)}, 10 \mathrm{mM}$ glucose, $40 \mathrm{~mm} \mathrm{KNO}_{3}, 25 \mathrm{~mm}\left(\mathrm{NH}_{4}\right)_{2} \mathrm{SO}_{4}$ and $0.1 \%$ casamino acids. Then the cells were incubated anaerobically for $4 \mathrm{~h}$ with the following additions. Lane A, no addition; lane B, $10 \mu \mathrm{M}$ ferric citrate; lane C, $100 \mu \mathrm{M} \mathrm{CuSO}_{4}$; lane D, $100 \mu \mathrm{M} \mathrm{CuSO}_{4}+10 \mu \mathrm{M}$ ferric citrate; lane $\mathrm{E}, 100 \mu \mathrm{M} \mathrm{CrCl}_{3}$; lane $\mathrm{F}, 100 \mu \mathrm{M} \mathrm{CrCl}_{3}+10 \mu \mathrm{M}$ ferric citrate; lane $\mathrm{G}, 100 \mu \mathrm{M} \mathrm{Ga}\left(\mathrm{NO}_{3}\right)_{3}$; lane $\mathrm{H}, 100 \mu \mathrm{M} \mathrm{Ga}\left(\mathrm{NO}_{3}\right)_{3}+10 \mu \mathrm{M}$ ferric citrate.

not induced by $\mathrm{CrCl}_{3}$ or $\mathrm{Ga}\left(\mathrm{NO}_{3}\right)_{3}$ (Fig. 3 lane $\mathrm{B}, \mathrm{I}$ ). When cells were grown in the PSG medium which contains Fe ions, $\mathrm{Cr}^{3+}$ or $\mathrm{Ga}^{3+}$ did not increase $\mathrm{Mn}$ SOD (Fig. 1). Therefore, $\mathrm{Cr}^{3+}$ or $\mathrm{Ga}^{3+}$ was added to the suspension of resting cells in the presence or absence of ferric citrate. The results (Fig. 4) show that ferric citrate inhibited the increase of Mn SOD by $\mathrm{Cr}^{3+}$ or $\mathrm{Ga}^{3+}$ (lane F, H), but did not inhibit the increase of $\mathrm{Mn} \mathrm{SOD}$ by $\mathrm{Cu}^{2+}$ (lane D).

\section{Characteristics of the new SOD band in the electrophoreogram}

When $\mathrm{CuSO}_{4}$ was added to the culture medium or to the incubation mixture, a new band of SOD activity appeared (Fig. 1 lane B, G, Fig. 2 lane C, G). Generally, SOD in various organisms occurs in three different molecular forms which contain $\mathrm{Cu}-\mathrm{Zn}, \mathrm{Fe}$ or $\mathrm{Mn}$ as the prosthetic metals. They can be distinguished from each other by their different sensitivities to cyanide and $\mathrm{H}_{2} \mathrm{O}_{2}$. The $\mathrm{Cu}-\mathrm{Zn} \mathrm{SOD}$ is 


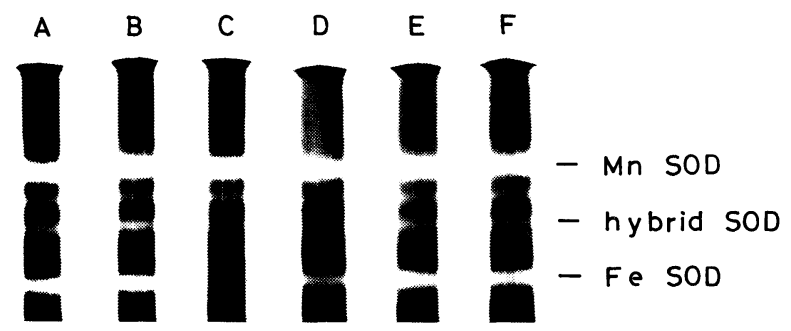

Fig. 5. Treatment of gels with cyanide, hydrogen peroxide or diethyldithiocarbamate (DDC) before staining SOD activity.

Cells, cultured anaerobically with $40 \mathrm{mM} \mathrm{KNO}_{3}$ for $18 \mathrm{~h}$, were harvested, washed and suspended in the incubation mixture as described in Fig. 2, then incubated anaerobically for $4 \mathrm{~h}$ with $40 \mathrm{mM} \mathrm{KNO}_{3}$ and $100 \mu \mathrm{M} \mathrm{CuSO}_{4}$. Crude extracts were prepared and subjected to polyacrylamide gel electrophoresis, then the gels were treated as follows before SOD activity staining. Lane A, soaked for $1 \mathrm{~h}$ in $50 \mathrm{~mm} \mathrm{~K}$-phosphate buffer (pH 7.8) and $0.1 \mathrm{~mm}$ EDTA; lane B, soaked for $1 \mathrm{~h}$ in $50 \mathrm{~mm} \mathrm{~K}$-phosphate buffer ( $\mathrm{pH} 7.8$ ), 0.1 mM EDTA and $1 \mathrm{~mm} \mathrm{KCN}$; lane C, soaked for $1 \mathrm{~h}$ in $50 \mathrm{~mm} \mathrm{~K}$-phosphate buffer (pH 7.8), 0.1 mM EDTA, $1 \mathrm{~mm} \mathrm{KCN}$ and $5 \mathrm{mM} \mathrm{H}_{2} \mathrm{O}_{2}$; lane D, soaked for $1.5 \mathrm{~h}$ in $50 \mathrm{~mm} \mathrm{~K}$-phosphate buffer (pH 7.8 ) and $1 \mathrm{~mm}$ DDC; lane E, soaked for $1.5 \mathrm{~h}$ in $50 \mathrm{~mm} \mathrm{~K}$-phosphate buffer (pH 7.8) and $2 \mathrm{~mm}$ DDC; lane F, soaked for $1.5 \mathrm{~h}$ in $50 \mathrm{~mm} \mathrm{~K}$-phosphate buffer (pH 7.8) and $5 \mathrm{~mm} \mathrm{DDC}$.

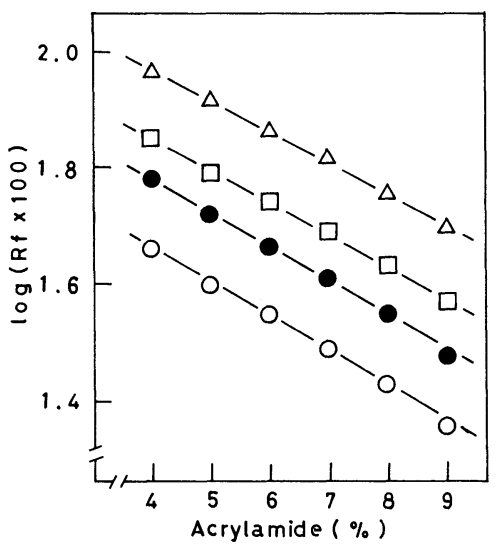

Fig. 6. Mobility of the superoxide dismutase as the function of polyacrylamide gel concentration.

Cells, cultured anaerobically with $40 \mathrm{mM} \mathrm{KNO}_{3}$ for $18 \mathrm{~h}$, were harvested, washed and suspended in the incubation mixture as described in Fig. 2, then incubated anaerobically for $4 \mathrm{~h}$ with $40 \mathrm{~mm} \mathrm{KNO}_{3}$ and $100 \mu \mathrm{M} \mathrm{CuSO}_{4}$. Crude extracts were prepared and applied to each of the gels of graded concentration of acrylamide and the $R f$-values of Mn SOD $(O)$, new $\operatorname{SOD}(\bullet)$, Hybrid SOD $(\square)$ or Fe SOD $(\triangle)$ were measured after electrophoresis.

inhibited by cyanide and $\mathrm{H}_{2} \mathrm{O}_{2}$, the Fe SOD is resistant to cyanide but inhibited by $\mathrm{H}_{2} \mathrm{O}_{2}$, and the $\mathrm{Mn}$ SOD is insensitive to both cyanide and $\mathrm{H}_{2} \mathrm{O}_{2}$. Furthermore, the $\mathrm{Cu}-\mathrm{Zn}$ SOD is inactivated by diethyldithiocarbamate (DDC). The results (Fig. 5) show that the SOD in the new band was resistant to cyanide (lane $\mathrm{B}$ ), $\mathrm{H}_{2} \mathrm{O}_{2}$ 
(lane C) or DDC (lane D, E, F), indicating that the new SOD has the characteristics of Mn SOD. The native polyacrylamide gel protocol developed by Hedrick and Smith (5) provides a method of estimating molecular size or charge of protein electrophoresis on gels containing successively higher concentrations of acrylamide. The results (Fig. 6) show that four parallel lines were obtained between plots for the logarithm of $R f$-values of the new SOD, Mn SOD, Hybrid SOD or Fe SOD, and acrylamide concentrations. The results show that the new SOD and the other three SODs have the same molecular size but have different charges.

\section{DISCUSSION}

Schiavone and Hassan (18) reported that $\mathrm{CuSO}_{4}$ added to E. coli cells growing by fermentation, did not induce Mn SOD synthesis. The present results (Fig. 1) also show that only weak Mn SOD activity appeared in the presence of $\mathrm{CuSO}_{4}$ when the cells were grown by fermentation, although a definite increase of $\mathrm{Mn}$ SOD by $\mathrm{CuSO}_{4}$ occurred when the cells were grown by nitrate respiration. There were dark brown precipitates in the culture medium containing $\mathrm{CuSO}_{4}$ when the cells were grown by fermentation, but not when grown by nitrate respiration. If the precipitates are copper compounds, the effective concentration of $\mathrm{Cu}$ ions in culture medium decreases when cells are grown by fermentation.

When $\mathrm{CuSO}_{4}$ was added to growing or resting cells, the gel electrophoreogram showed a new band of SOD, which was shown to be a charge isomer of Mn SOD. Both the increase in the activity of Mn SOD and the appearance of the new isozyme of $\mathrm{Mn} \mathrm{SOD}$ caused by $\mathrm{Cu}$ ions were the results of de novo protein synthesis, since they were completely inhibited by chloramphenicol. In resting cells, the synthesis of $\mathrm{Mn}$ SOD required the operation of nitrate respiration, but that of the new enzyme did not (Fig. 2). Privalle et al. (15) reported that E. coli bearing multicopy plasmid carrying the Mn SOD gene can produce an enzymatically inactive form of Mn SOD (pro-Mn SOD) in the cells grown by fermentation. In view of that report, the result of our present study can be explained as follows: under anaerobic conditions, $\mathrm{Cu}$ ions stimulated the pro-Mn SOD synthesis and converted it to the charge isomer of Mn SOD, while the pro-Mn SOD was converted to the Mn SOD by nitrate respiration. But this does not explain the results that the Mn SOD synthesis in growing cells by $\mathrm{CuSO}_{4}$ did not require the operation of nitrate respiration (Fig. 1). Further examination is necessary whether the explanation is appropriate or not, particularly concerning the role of $\mathrm{Cu}$ ions and the effect of nitrate respiration on the synthesis of these enzymes.

In the present experiment, $\mathrm{Cr}$ ions or $\mathrm{Ga}$ ions did not affect the level of $\mathrm{Mn}$ SOD in the cells grown anaerobically in the PSG medium (Fig. 1). In contrast, the addition of these ions to the incubation mixture increased Mn SOD activity after anaerobic incubation of resting cells, but simultaneous addition of $\mathrm{Fe}$ ions diminished the stimulatory effect of these ions on Mn SOD synthesis (Fig. 4). Since the PSG medium contained $\mathrm{FeCl}_{3}$, the $\mathrm{Cr}$ ions or $\mathrm{Ga}$ ions in the PSG medium 
could not increase the level of Mn SOD. Moody and Dailey (13) reported that iron transport in Rhodopseudomonas spheroides required the electrical component of proton motive force and this uptake was inhibited by Ga ions. Several workers have noted that $\mathrm{Fe}$ ions repress $\mathrm{Mn} \operatorname{SOD}$ synthesis $(12,16,17,19)$. Therefore, the effect of $\mathrm{Ga}$ and $\mathrm{Cr}$ ions on Mn SOD synthesis is probably due to the inhibition of iron uptake, although the mechanism of the inhibition is still unknown. The increase of $\mathrm{Mn} \mathrm{SOD}$ by the addition of $\mathrm{Cu}$ ions during the incubation of resting cells was not inhibited by $\mathrm{Fe}$ ions. Therefore, the effect of $\mathrm{Cu}$ ions on the increase of Mn SOD does not appear to be due to the inhibition of the uptake of Fe ions.

\section{REFERENCES}

1) Beauchamp, C. and Fridovich, I., Superoxide dismutase: Improved assay and assay applicable to acrylamide gels. Anal. Biochem., 44, 276-287 (1971).

2) Clare, D. A., Blum, J., and Fridovich, I., A hybrid superoxide dismutase containing both functional iron and manganese. J. Biol. Chem., 259, 5932-5936 (1984).

3) Dougherty, H. W., Sadowski, S. J., and Baker, E. E., A new iron-containing superoxide dismutase from Escherichia coli. J. Biol. Chem., 253, 5220-5223 (1978).

4) Hassan, H. M. and Moody, C. S., Regulation of manganese-containing superoxide dismutase in Escherichia coli. J. Biol. Chem., 262, 17173-17177 (1987).

5) Hedrick, J. L. and Smith, A. J., Size and charge isomer separation and estimation of molecular weights of proteins by disc gel electrophoresis. Arch. Biochem. Biophys., 126, 155-164 (1968).

6) Itzhaki, R. F. and Gill, D. M., A micro-biuret method for estimating protein. Anal. Biochem., 9, 401-410 (1964).

7) Keele, B. B. Jr., McCord, J. M., and Fridovich, I., Superoxide dismutase from Escherichia coli B. J. Biol. Chem., 245, 6176-6181 (1970).

8) Lodge, J. S. and Emery, T., Anaerobic iron uptake by Escherichia coli. J. Bacteriol., 160, 801-804 (1984).

9) Miyake, K., Effect of nitrate on the level of superoxide dismutase in anaerobically grown Escherichia coli. J. Gen. Appl. Microbiol., 32, 527-533 (1986).

10) Miyake, K. and Hino, S., Effect of anaerobic respiration on the level of superoxide dismutase in Escherichia coli. J. Gen. Appl. Microbiol., 34, 105-109 (1988).

11) Miyake, K. and Hino, S., Anaerobic induction of superoxide dismutase in Escherichia coli by nitrate respiration. J. Gen. Appl. Microbiol., 34, 475-483 (1988).

12) Moody, C. S. and Hassan, H. M., Anaerobic biosynthesis of the manganese-containing superoxide dismutase in Escherichia coli. J. Biol. Chem., 259, 12821-12825 (1984).

13) Moody, M. D. and Dailey, H. A., Iron transport and its relation to heme biosynthesis in Rhodopseudomonas sphaeroides. J. Bacteriol., 161, 1074-1079 (1985).

14) Privalle, C. T. and Fridovich, I., Inductions of superoxide dismutases in Escherichia coli under anaerobic conditions. J. Biol. Chem., 263, 4274-4279 (1988).

15) Privalle, C. T., Beyer, W. F., Jr., and Fridovich, I., Anaerobic induction of proMn-superoxide dismutase in Escherichia coli. J. Biol. Chem., 264, 2758-2763 (1989).

16) Pugh, S. Y. R., DiGuiseppi, J. L., and Fridovich, I., Induction of superoxide dismutase in Escherichia coli by manganese and iron. J. Bacteriol., 160, 137-142 (1984).

17) Pugh, S. Y. R. and Fridovich, I., Induction of superoxide dismutases in Escherichia coli B by metal chelators. J. Bacteriol., 162, 196-202 (1985).

18) Schiavone, J. R. and Hassan, H. M., The role of redox in the regulation of manganese-containing superoxide dismutase biosynthesis in Escherichia coli. J. Biol. Chem., 263, 4269-4273 (1988). 
19) Touati, D., Transcriptional and posttranscriptional regulation of manganese superoxide dismutase biosynthesis in Escherichia coli, studied with operon and protein fusions. J. Bacteriol., 170, 2511-2520 (1988).

20) Yost, F. J. Jr. and Fridovich, I., An iron-containing superoxide dismutase from Escherichia coli. J. Biol. Chem., 248, 4905-4908 (1973). 